\title{
Animal Health in the Tropics
}

\author{
M.R. Jainudeen and A.R. Sheikh-Omar
}

\author{
Faculty of Veterinary Medicine and Animal Science, University Pertanian Malaysia, \\ 43400 Serdang, Selangor, Malaysia
}

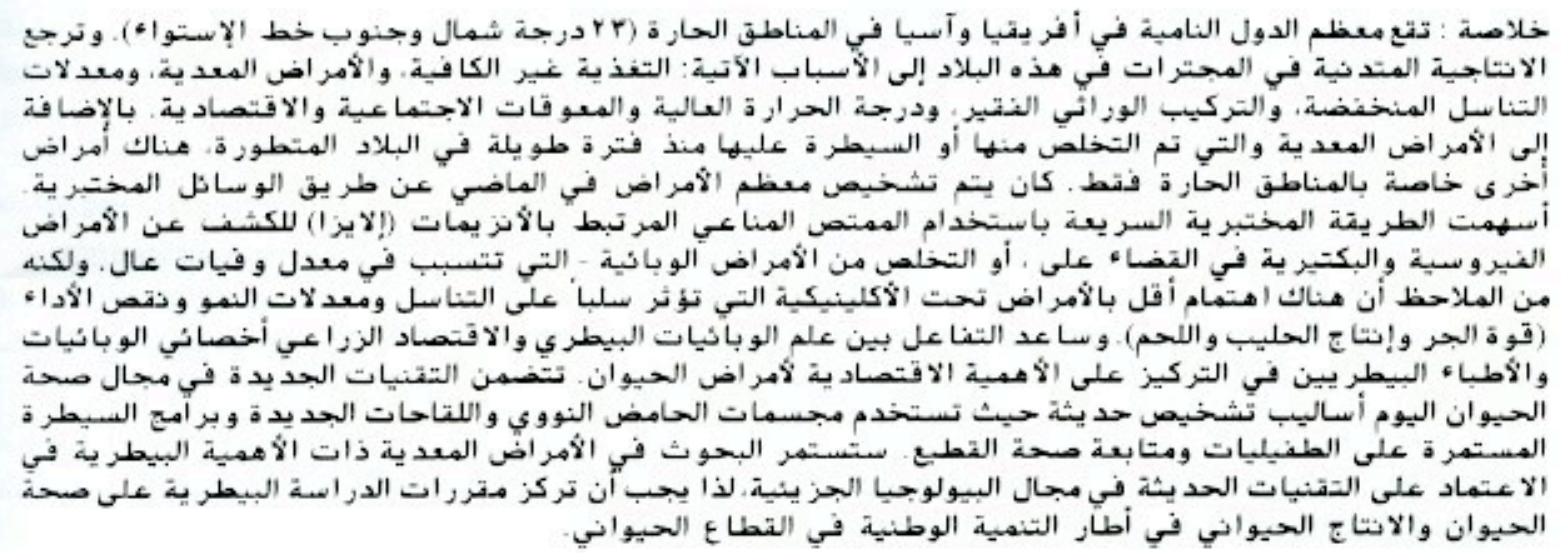

\begin{abstract}
Most developing countries in Africa and Asia are located in the tropics ( $23^{\circ}$ north and south of the equator). The poor productivity of ruminants in these countries is mostly due to inadequate nutrition, infectious diseases, low rates of reproduction, poor genotype, high ambient temperatures and socioeconomic constraints. In addition to infectious diseases which have long since been eradicated or brought under control in developed countries, there are diseases unique to the tropical environment. In the past, the diagnosis of most diseases was based on serological tests. The enzyme-linked immunosorbent assay (ELISA), a rapid method of identifying viral and bacterial infections, is contributing to the eradication or control of most epidemic diseases which inflict high mortality. Less attention has, however, been given to subclinical diseases which adversely affect reproduction, growth rates and reduced performance (draught power, milk and meat). The interaction of veterinary epidemiology and agricultural economics has helped epidemiologists and veterinarians to focus on the economic importance of animal diseases. The emerging trends in animal health include new diagnostic methods using DNA probes, new vaccines, sustainable parasite control schemes and herd health monitoring. The study of infectious diseases of veterinary importance will continue to be supported by modern techniques of molecular biology. Veterinary curricula should emphasise both animal health and production in the context of current national development occurring in the livestock sector.
\end{abstract}

F or purposes of this paper, we prefer the term "tropics" to a "hot" climate because our experiences relate to animal health in the tropics. The tropics is the region lying between latitude $23^{\circ}$ north and south of the equator and is characterized by great extremes of temperature and rainfall as well as by a diversity of social, religious and farming practices. More than $50 \%$ of cattle, $75 \%$ of buffaloes (Bubalus bubalis), $25 \%$ of sheep and $60 \%$ of goats in the world are found in the tropics. Yet they produce less than half of the world's requirement for milk and meat. There are many reasons for this scenario, but the most important are inadequate nutrition due to poor quality of feed resources, poor health resulting from infectious diseases, low rates of reproduction, poor genetic potential of existing indigenous animal breeds and high ambient temperatures.

During the past two decades, the subject of animal health in the tropics has received considerable attention. International conferences devoted specifically to the African and Asian continents have been held in Ibadan (Loosli et al., 1974), Townsville (Anon, 1980) and Kuala Lumpur (Jainudeen and Omar, 1982; Jainudeen et al., 1986). Much progress and advances have occurred during the past decade.

This paper deals with the current status of animal health in developing countries in the tropical Africa and Asia, recent advances in disease diagnosis and control and emerging trends which are applicable to improving the health status of ruminants in these countries.

\section{Basic Concepts in Animal Health}

Animal health is concerned with the maintenance of a disease-free population of animals. It encompasses the disciplines of preventive veterinary medicine, veterinary microbiology, regulatory veterinary medicine, veterinary epidemiology and economics, and herd health management. 
TABLE 1

Classification of Disease Types ${ }^{2}$.

\begin{tabular}{|c|c|c|c|}
\hline Class & Definition & Example & Significance \\
\hline Epidemic & $\begin{array}{l}\text { occurs in a population in excess of its normally } \\
\text { expected frequency of occurrence - affects } \\
\text { many animals in a region at the same time }\end{array}$ & $\begin{array}{l}\text { foot and } \\
\text { mouth } \\
\text { disease }\end{array}$ & economically very important \\
\hline Endemic & $\begin{array}{l}\text { occurs in a population with predictable } \\
\text { regularity and with only minor changes from its } \\
\text { normally expected frequency - low incidence but } \\
\text { constantly present in a given in a population }\end{array}$ & parasitic gastro- enteritis & $\begin{array}{l}\text { less contagious but economically } \\
\text { significant }\end{array}$ \\
\hline Sporadic & is normally absent in a susceptible population & babesiosis & should be monitored and controlled \\
\hline "Sub-clinical" & no overt signs of the disease & infertility & affects production \\
\hline Zoonotic & $\begin{array}{l}\text { can secondarily be transmitted from animal to } \\
\text { man }\end{array}$ & brucellosi & \\
\hline
\end{tabular}

DISEASE: A disease may be defined as a derangement in the function of the whole or part of the host whereas infection is the invasion of a living organism (host) by another living organism, the agent. The major determinants influencing the outcome and incidence of a disease are: the causative agent ( genetic, physical, infectious, chemical or nutritional); the host (age, species, breed, sex, genetic resistance and immunologic status); and the environment (management, nutrition, thermal stress, socioeconomics).

A diseased animal may exhibit clinical signs such as fever, lameness, ulcers, poor growth and draught ability or subclinical signs such as failure to conceive, poor production in terms of meat and milk. While diseases showing clinical signs are easily diagnosed and controlled, it is the insidious nature of subclinical diseases that makes diagnosis difficult as the effects are not dramatic. The economic effects of the latter may be more serious because they cause longterm effects on fertility, growth rate and work capacity.

The outcome of a disease may be death (acute), survival with the disease (chronic or subclinical) or recovery with strong immunity. The distribution of disease events in a population can be described as epidemic, endemic, sporadic, "subclinical" or zoonotic (Table 1).

IMMUNITY: It is the ability of the host to defend itself from an invading infectious agent (antigen). The immune response includes the production of protective antibodies (humoral response) and the activation of antigen-specific cellular response (cell-mediated response). The effectiveness of the immunity - natural or acquired, specific or nonspecific, active or passive - will depend upon the infecting dose, the nutritional state of the animal and the presence of concurrent infections.

The antigen-antibody reaction is the basis for serological diagnosis of disease. Some organisms induce high antibody titres that can be detected by serological tests making it possible to classify animals into infected and uninfected groups. Other organisms produce low titres which are difficult to detect by current serological methods.

An animal can be protected from an infectious agent (immunization) by either active or passive methods. In active immunization (vaccination), the infectious agent (antigen) - live, modified or killed is inoculated whereas in passive immunization, serum rich in specific antibody is injected into the animal at risk or vaccination of the dam in order to provide the newborn with passive maternal immunity via colostral antibodies. The immunity conferred through active immunization is usually long-term whereas that of passive immunization short-term.

\section{Current Status of Animal Health in the Tropics}

INFECTIOUS DISEASES: Ruminants in developing countries provide financial security and are utilised directly (slaughter or sale) a indirectly (milk, and draught power). Their health, however, remains one of the main constraints to productivity. Infectious diseases associated with high mortality rates inflict severe financial losses in terms of draught power, milk and meat whereas chronic wasting diseases and low reproductive rates reduce their productive performance. They suffer not only from infectious diseases existing in developed countries, but also from other diseases which have long since been eradicated or brought under control in developed countries (rinderpest) or those 
unique to the tropical environment (trypanosomiasis). It is beyond the scope of this paper to list all the diseases of ruminants in the developing countries. Instead, the infectious diseases of economic importance which are of major concern to both Africa and Asia are listed (Table 2).

Vaccination is the popular method of controlling infectious diseases in developing countries (Table 3). Slaughter is not practised due to social, cultural and political sentiments. The main problems associated with vaccination are:

(a) the exposure to high ambient temperatures may inactivate live vaccines and will also make nonreplicating vaccines less immunogenic;

(b) the inability to maintain the cold chain from the manufacturer to animals in hot remote rural areas;

(c) the use of serotypes in the vaccine different from those in the field; and

(d) the failure to adhere to the vaccination regimes due to poor husbandry practices.

INFERTILITY: Despite the control of many epidemic and endemic diseases, animal productivity has been stagnant due to "subclinical diseases" such as low reproductive rates (infertility). Infertility in ruminants may be due to infectious and noninfectious causes. Except for brucellosis, the role of other diseases (vibriosis, trichomoniasis, leptospirosis and infectious bovine rhinotracheitis) in ruminant infertility remains obscure.

Many noninfectious factors - poor nutrition, breeding management and thermal stress - adversely affect female fertility (Jainudeen, 1985; 1988). Inadequate nutrition and thermal stress alter the length of oestrous cycles, reduce duration and intensity of oestrus and in extreme cases suppress the oestrous cycle (anoestrus). In draught animals, thermal stress could further aggravate early embryonic mortality.

ANIMAL HEALTH CARE: In developed countries, animal health care is provided by two sectors. The Government veterinary services deal with disease prevention and control in large animal populations whereas private veterinary practitioners provide a curative service to individual farmers. Historically, the veterinary services in many developing countries, particularly in tropical Asia and Africa, have been the domain of the government service. Its primary function is prevention and control of diseases while its secondary function is to provide curative service for individual animals. Among the causes for the decline in the quality of the Government veterinary services, the most important are the weakening of indigenous and government structures, the restrictive veterinary policies and the strong decline in the operational capability of the veterinary services (Haan et al., 1992). Very few private practitioners serve the ruminant sector because most farmers in the developing countries cannot afford the cost of a such a service.

\section{Recent Advances in Animal Health}

During the past decade, several advances have been made in animal health which have potential applications in the livestock industries of developing nations. They include sensitive immunoassays for disease diagnosis and monitoring and fertility investigations, and the application of biotechnology for the production of novel vaccines and gene transfer.

DiSEASE DIAGNosis AND CONTROL: Before animal diseases can be controlled or eradicated, it is necessary to diagnose the specific disease, establish its prevalence and distribution and monitor efficacy of control programmes. Until recently, laboratory diagnosis of animal diseases was based on serological assays relying on an initial antigen-antibody reaction and indicator system, e.g., serum neutralization, complement fixation, immunofluorescence and agglutination tests. A recently developed serological technique based on an enzyme as the indicator, is the enzyme-linked immunosorbent assay (ELISA). A common application of ELISA is the monitoring of antibody response after vaccination, and the detection of disease outbreaks in a herd of animals. It combines simplicity, economy and low cost with speed, sensitivity and specificity, and is amenable to complete automation to increase efficiency.

FERTILITY: In the past, veterinarians diagnosed fertility problems in cattle and buffalo solely by rectal palpation of the reproductive organs. The diagnosis was often based on the skill and experience of the operator. Progesterone, a key hormone in the function of the ovary can now be measured in a sample of milk or serum by a highly sensitive radioimmunoassay (RIA). It has helped to elucidate the reasons for the lower reproductive efficiency of indigenous cattle, buffalo, sheep and goat in developing countries. The progesterone RIA provides an early diagnosis of nonpregnancy, diagnoses endocrine disorders and improves the efficiency of artificial insemination. Besides the RIA, other diagnostic techniques for research in animal reproduction are available include laparoscopy, a simple method of determining ovulation rates of goats and sheep for breed evaluation and ultrasonography for diagnosis of pregnancy in sheep and goats (Jainudeen, 1994).

Biotechnology: Most serological and biochemical tests fail to differentiate closely-related viral or 
TABLE 3

Immunization Against Viral and Bacterial Diseases of Ruminants in the tropics"

\begin{tabular}{|c|c|c|c|c|c|}
\hline Disease & $\begin{array}{l}\text { type of } \\
\text { vaccine }\end{array}$ & Species & $\begin{array}{c}\text { Age } \\
\text { Month }\end{array}$ & Dose & $\begin{array}{c}\text { Re- } \\
\text { vaccination }\end{array}$ \\
\hline \multicolumn{6}{|l|}{ Viral } \\
\hline Rinderpest & $\begin{array}{l}\text { attenuated } \\
\text { live } \\
\text { virus' }\end{array}$ & cattle, buffalo, & , $\quad 6-8$ & single & none \\
\hline $\begin{array}{l}\text { Peste des } \\
\text { Petits } \\
\text { Ruminants } \\
\text { (Rinderpest } \\
\text { virus) }\end{array}$ & $\begin{array}{l}\text { attenuated } \\
\text { live virus }\end{array}$ & goat, sheep & 3 & single & none \\
\hline $\begin{array}{l}\text { Foot \& Mouth } \\
\text { Disease }\end{array}$ & $\begin{array}{l}\text { inactivated } \\
\text { virus }^{x=}\end{array}$ & $\begin{array}{l}\text { cattle, buffalo } \\
\text { goat, sheep }\end{array}$ & $\begin{array}{l}1 \\
3-4\end{array}$ & $\begin{array}{l}\text { single } \\
\text { single }\end{array}$ & $\begin{array}{l}4-12 \mathrm{~m} \\
\text { annual }\end{array}$ \\
\hline Blue tongue & $\begin{array}{l}\text { attenuated } \\
\text { live virus² } \\
\text { (polyvalent) }\end{array}$ & sheep.goat & $3-6$ & $\begin{array}{c}2 \text { doses } \\
\text { at } 3- \\
\text { week } \\
\text { interval }\end{array}$ & annual \\
\hline \multicolumn{6}{|l|}{ Mycoplasmal } \\
\hline $\begin{array}{l}\text { Contagious } \\
\text { Bovine }\end{array}$ & $\begin{array}{l}\text { attenuated } \\
\text { live culture }\end{array}$ & cattle & & single & $\begin{array}{l}\text { twice a } \\
\text { year" }\end{array}$ \\
\hline \multicolumn{6}{|l|}{$\begin{array}{l}\text { Pleuro- } \\
\text { pneumonia }\end{array}$} \\
\hline \multicolumn{6}{|l|}{ Bacterial } \\
\hline $\begin{array}{l}\text { Haemorrhagic } \\
\text { septicemia }\end{array}$ & $\begin{array}{l}\text { killed culture } \\
\text { (oil adjuvant) } \\
\text { killed culture } \\
\text { (alum } \\
\text { precipitated) }\end{array}$ & $\begin{array}{l}\text { cattle,buffalo } \\
\text { cattle,buffalo }\end{array}$ & $4-12$ & $\begin{array}{l}\text { single } \\
\text { single }\end{array}$ & $\begin{array}{l}\text { annual } \\
\text { in the face } \\
\text { of an } \\
\text { outbreak }\end{array}$ \\
\hline Anthrax & live spores & cattle, buffalo & & single & \\
\hline Blackleg & killed culture & cattle & 4 & single & \\
\hline \multirow[t]{2}{*}{ Bnucellosis } & $\begin{array}{l}\text { live culture } \\
\text { (S19) }\end{array}$ & cattle, buffalo & $\begin{array}{c}4.8 \\
\text { female }\end{array}$ & single & none \\
\hline & $\begin{array}{l}\text { killed culture } \\
\text { with adjuvant } \\
\text { (S45/20) }\end{array}$ & cattle & $\begin{array}{l}\text { adult } \\
\text { female }\end{array}$ & $\begin{array}{c}\text { single } \\
2 \text { doses } \\
\text { at } 6- \\
\text { week } \\
\text { interval }\end{array}$ & \\
\hline $\begin{array}{l}\text { Pneumonic } \\
\text { pasteurellosis }\end{array}$ & killed culture & sheep,goat & & & \\
\hline
\end{tabular}

the International Atomic Energy Agency (IAEA), Australian Centre for International Research (ACIAR), International Research on Animal Diseases (ILRAD), International Livestock Centre (ILCA) International Research and Development Centre (IDRC) and other international agencies. These agencies provide technical assistance to eradicate or control the epidemic diseases which inflict high mortality as well as endemic and sporadic diseases. However, the importance of subclinical diseases which adversely affect draught power, milk and meat has not received much attention. A multidisciplinary approach is needed to ascertain the factors inhibiting productivity. Modern veterinary epidemiology and economics encompass tools and knowledge that are needed in responding to these changes (Dorn 1992).
VETERINARY EPIDEMIOLOGY AND ECONOMICS: Epidemiology can be regarded as the foundation of animal health. It is the use of specific techniques of data gathering and analysis to describe disease in a population as a basis for determining appropriate control measures and evaluating their effectiveness. It is equally applicable in the investigations of noninfectious diseases and fertility problems.

The interaction of veterinary epidemiology and agricultural economics has helped epidemiologists and veterinarians to focus on the economic importance of animal diseases. With the shift from an extensive to a more intensive production system, animal disease problems will be less tolerated by producers and consumers. The livestock industries will expect a rapid veterinary response to new animal health threats. A need exists to determine the economics of contro: measures proposed or implemented.

\section{DISEASE CONTROL: Genetic Resistance. The} exploitation of livestock possessing genetic resistance is receiving serious attention where conventional disease control programmes are expensive to implement or drugs and vaccines are not available. Several trypanotolerant breeds of cattle have already been identified. The West African Shorthorn and N'Dama cattle and the East African Boran exhibit tolerance to trypanosomiasis and are able to survive in tsetse infested areas of Africa. Strategies for permanent alteration of traits by gene transfer, initially directed to improving growth, are now shifting in emphasis towards the transfer of genes for disease resistance. The role of recombinant DNA technology in the development of diagnostic probes for use in genetic selection programmes is also expanding rapidly. (Robinson and McEvoy, 1993).

Improved Field and Laboratory Diagnostic Services. Recognising that developing countries are encountering many constraints in the control or eradication of infectious disease, the FAO/IAEA Agricultural Laboratory, Seibesdorf, in collaboration with several national laboratories, has pioneered the development of ELISA kits for detecting specific antigens or antibodies relative to several diseases. The reagents for the test are prepared in bulk and packaged as "kits". Besides being cheaper and faster than previous serological tests, the results from different centres can be compared because the same reagents and instructions are provided to the participant centres. The ELISA has been employed to diagnose and monitor the effectiveness of vaccination programmes of major diseases such as rinderpest, trypanosomiasis, haemorrhagic septicemia, brucellosis in Africa and Asia (see IAEA, 1994). 
Vaccines. New commercial and experimental vaccines for viral and bacterial diseases are being evaluated worldwide. Viral vaccines include gene-deleted modified live (MLV), subunit and peptide antigens. Newer Pasteurella vaccines are composed of either MLV, or bacteriocins supplemented with toxoid or surface antigens. Delivery of multiple-subunit antigens with optimal immune response induction has led to the investigation of attenuated heterologous viral and bacterial expression vectors such as BHV-1, vaccinia and Salmonella spp (Yancey, 1992).

A vaccinia virus recombinant vaccine has been developed for rinderpest which protects cattle against challenge by more than 1000 times the lethal dose of the virus (Yilma, 1989). The recombinant overcomes the major logistical problems of the tissue culture vaccine that failed to eradicate rinderpest by vaccination. It can be easily propagated and administered by scarification as in smallpox. A distinct advantage in the hot and arid regions of Africa and Asia is that the lyophilized form of vaccinia virus is heatstable and does not require refrigeration.

Parasite Control. The dangers of resistance, residues and ecotoxicity are of increasing concern to the future of anthelmintics to effectively control nematode parasites in ruminants. Sustainable parasite control schemes are being developed and implemented which will minimise anthelmintic use and still maintain high levels of profitability of the farming enterprise. There is growing awareness on the better use of existing drugs to maximise their effectiveness and minimise the selection for resistance and impact on the environment. In the future it is expected that other non-chemotherapeutic options will become available, e.g. helminth vaccines, resistance hosts, biological control, nematode growth regulators, which will revolutionise the current thinking on nematode parasite control of livestock (Waller, 1993).

Animal quarantine. It is the isolation imposed on an animals entering a country or establishment so that any disease(s) they may be harbouring or incubating can be identified. As international movement of live animals for breeding programmes increases and with greater use of aerial transport, stricter quarantine regulations are necessary to protect the developing livestock industries in the tropics. Quarantine may also be imposed on imported animal products; the period of quarantine depends on the incubation period of the specific diseases.

Developing countries should seek appropriate technical and socioeconomic advice to reduce the importation of diseases with live animals or through semen. The Office International des Epizoites (O.I.E) provides guidelines on international trade in animals and animal products through the International Animal
Health Code (O.I.E, 1992). The code defines the minimum health guarantees required of trading partners, so as to avoid the risk of spreading animal diseases. In addition, it provides details of laboratory diagnostic techniques and protocols for the production and control of biological products (in particular vaccines), lists of diseases giving the animal health conditions which a country has to fulfil in case of the disease occurring in its territory, in order that it can export live animals, semen, embryos, meat and dairy products and recommendations for air transport of animals

HeRd HEALTH MONITORING: Herd health monitoring, extensively practised in commercial dairy herds in developing countries, is being adapted to optimise productivity in smallholder dairy farming systems in Kenya, Malaysia, Thailand, India, Pakistan and Sri Lanka. The objectives of the programme are to maintain economically optimal level of disease control, extract maximum profit and improve quality of life of the farmer.

COMPONENTS: The major components are client education, animal reproduction, nutrition, general health including mastitis control, record keeping and an emergency veterinary service. The potential benefits are optimal calving intervals and reduced culling for fertility problems. It must be emphasized that treatment and control of fertility problems can only be justified if they oftimize the calving interval.

A herd health programme emphasises the reproduction and lactational cycle. Besides reproductive management, other tasks such as routine vaccinations, mastitis control and parasite control may be undertaken during these routine visits.

RECORDS: In most herds and flocks, records are rarely kept by livestock farmers as there is no economic necessity. A system of accurate records facilitates assessment of the effectiveness of the programme. Accurate knowledge on reproductive health and milking history of each cow aids dramatically in determining the value of the individual animal to the herd. It is primarily a service of consultation, depending upon the rapport between farmer and veterinarian for its effectiveness. The second consideration is continuity and requires the continuous supervision by the veterinarian cooperating with pathologists, nutritionist, animal scientists and agrostologists. The overall concept is to reduce the effects of disease to economically acceptable levels by a regular assessment of performance as seen both in the records and in the animals themselves. 
Subclinical Diseases AfFecting Production: Subclinical diseases affecting production in developing countries attracted the attention of several international agencies and centres. At the International Laboratory for Research on Animal Diseases (ILRAD, 1992), the focus is primarily on immunological and related aspects of trypanosomiasis and tick-borne diseases. The diagnosis, epidemiology, antigens, molecular genetics, host immune responses and the genetics of host resistance are being studied. Also ILRAD is investigating the factors that govern the successful application of improved animal health. Research is being conducted on pneumonic pasteurellosis in sheep and goats at the University Pertanian Malaysia and Moredan Institute, Edinburgh

VETERINARY SERVICES: Disease control services are important inputs into livestock sector development. The World Bank gives $15 \%$ of its livestock lending to veterinary health improvements. In many developing countries many traditional functions of the public sector are being transferred to private operators. Haan et al. (1992) presents an overview of the economic concepts underlying the efficiency of delivery of veterinary services and that subsequently govern private and public sector roles, the progress in privatization of veterinary services, including some examples of successful privatization; and the future technology needs and policy requirements to facilitate privatization.

VETERINARY EdUCATIONAL NEedS: As the livestock sector expands, the demand for veterinary services will continue to increase. Veterinary education cannot remain static but must continually develop to reflect the trends in the livestock sector. The major difficulty in predicting the needs for veterinary education is assessing the future directions. The horizons would continue to hold a place for livestock species reared for milk, meat and eggs. The trend would be towards intensification of livestock enterprises and veterinarians would be expected to provide delivery systems on optimizing productivity with the best use of available resources.

VETERINARY CURRICULA: The veterinary undergraduate curriculum in most developing countries is directed towards the teaching of veterinary medicine and surgery of domestic animals. Some veterinary schools are restructuring their curricula to emphasise both animal health and production in the context of current national development occurring in the livestock sector. Before reviewing the curriculum, surveys should be conducted within the veterinary profession, including recent graduates and livestock agencies to assess the relevance of the curriculum to national and community needs of the future.

MODEL VETERINARY PRACTICE: Establishment of model veterinary practices in developing countries should be promoted. In this respect, the ambulatory clinics of veterinary schools should be expanded to simulate a private veterinary practice. Model practices should be established in selected parts of the country where there is a potential for such a service. Foreign funding may be required to employ foreign private practitioners on a short-term basis to establish these practices, equipment, supplies and overseas fellowships for veterinarians.

Veterinary Epidemiology and Economics Unit: The emphasis given to veterinary epidemiology worldwide necessitates the creation of the Veterinary Epidemiology and Economics Unit within veterinary schools in Africa and Asia. Through the ambulatory field service, model veterinary practices, research institutes and the private sector, these units should able to gather data and clinical materials for student teaching. It could also develop teaching models in herd and population medicine and participate in disease surveillance programmes.

Continuing Education Programme: Continuing education programmes for updating the knowledge and skills of veterinarians already in practice could provide a more effective service to the livestock sector. Future programmes should include workshops, seminars, clinical and diagnostic demonstrations, and farms visits. University libraries should be strengthened by regular purchase of textbooks and journals as well as audiovisual programmes in animal health and production. New forms of training would remove the need for participants to take time away from their practice and more resources should be considered in marketing audio and visual materials.

RESEARCH: With intensification of livestock industries, new problems in feeding, breeding, management and disease control will emerge. Developing countries must, therefore, intensify their research capabilities by developing postgraduate programmes. It would then be possible to encourage veterinarians to solve field problems through postgraduate research in their own countries.

Close collaboration with foreign veterinary faculties and research institutes could enable the exchange information in specialized fields. In this context, the establishment of Postgraduate Institute of Tropical Animal Health and Production in different regions of Africa and Asia could organize and coordinate postgraduate research and training courses 


\section{JAINUDEEN AND SHEIKH-OMAR}

for veterinary practitioners and animal science specialists. These institutes could also attract visiting researchers and foreign postgraduate students wishing to specialize in tropical animal health and production.

\section{Conclusions}

Animal health is concerned with maintenance of a disease-free population of animals. But infectious diseases adversely affect animal health by reducing the amount and quality of food and fibre, and draft power in the tropics. Epidemic diseases such as rinderpest have caused massive mortality among cattle and buffalo. Trypanosomiasis and Foot-and-mouth disease can cause high morbidity and great direct economic loss, and loss of markets through trade barriers.

Control of animal diseases must deal with disease agents, their hosts and vectors, as part of ecosystems and farming systems. More attention, therefore, should be given to better disease surveillance, diagnosis and reporting. Newer diagnostic methods based on ELISA and DNA probes should be used to diagnose and control animal disease,

Developing countries must launch their own research programmes in biotechnology, so that they are not solely dependent on industrialised countries for new products and research. With the development of recombinant vaccines, the prospects of eradicating rinderpest in Asia and Africa seem to be good. The economics of disease loss and the benefits of interventions must become part of the decision-making process. In this respect, veterinary epidemiology and economics has an important role to play in developing countries. Future veterinarians should have a sound knowledge of integrating production with animal health and be able to provide advice and strategies to minimise animal diseases and maximise productivity.

\section{References}

Anon. 1980. Animal Health in the Tropics. James Cook University, Townsville.

Binns, M.M. 1993. The application of molecular biology to the study of veterinary infectious diseases. British Veterinary Journal 149: 21 .
Campbell, R.F.S. 1982. The control of infectious diseases in the Asian and Australasian region. In: M.R. Jainudeen and A.R. Omar (Ed.) Animal Production and Health in the Tropics. pp 77-84. University Pertanian Malaysia Press, Serdang.

Dorn, C.R .1992. Veterinary epidemiology and its economic importance in A.D. 2000. Preventive Veterinary Medicine. 13: 129 .

Haan, C de., D.L Umali and C. De-Haan . 1992. Public and private sector roles in the supply of veterinary services. In: J.R. Anderson and C. de Haan (Ed.). Proceedings of the twelfth agricultural sector symposium pp 125-137 Washington, D.C., USA; World Bank.

IAEA. 1994. Strengthening research on animal reproduction and disease diagnosis in Asia through the application of immunoassay techniques. TECDOC-736, Vienna, Austria.

ILRAD. 1992. Annual Report of the International Laboratory for Research on Animal Diseases. International Laboratory for Research on Animal Diseases.1992, 84 pp. Nairobi, Kenya.

Jainudeen, M.R. and A.R. Omar (Ed.). 1982. Animal Production and Health in the Tropics. pp 77-84. University Pertanian Malaysia Press, Serdang.

Jainudeen, M.R. 1985. Reproduction in draught animals: Does work affect female fertility? In: J.W. Copland (Ed.) Draught Animal power for Production. pp 130-133 ACIAR Series No. 10, Canberra.

Jainudeen, M.R., M.M. Mahyuddin and J.E. Huhn (Ed.). 1986. Livestock Production and Diseases in the Tropics. Proc. 5th International National Conference of Tropical Veterinary Medicine, August 18-22, 1986. University Pertanian Malaysia, Serdang.

Jainudeen, M.R. 1988. Management of reproduction in female farm animals in the tropics. Proc. 11th Int. Congr. Anim. Reprod. \& AI. Vol. 5, pp 246-254. Dublin, Ireland.

Jainudeen, M.R. 1994. Laparoscopy and Ultrasonography in animal Reproduction Research. In: Strengthening research on animal reproduction and disease diagnosis in Asia through the application of immunoassay techniques. pp 101-106. TECDOC-736, Vienna, Austria.

Loosli, J.K., V.A. Oyenuga and G.M. Babatunde (Ed.). 1973. Animal Production in the Tropics. Heinemann Educational Books (Nigeria) Limited, Ibadan.

Office International des Epizooties. 1992. International animal health code: mammals, birds and bees. 1992, Ed. 6, 550 pp. Paris 75017, France.

Robinson, J.J, T.G. McEvoy. 1993. Biotechnology - the possibilities. Animal Production. 1993, 57; 335.

Yancey, R.J. Jr. 1992. Recent advances in vaccine technology. Journal of Dairy Science. 1992, 75: Supplement 1, 218.

Yilma, T.D. 1989. Prospects for the total eradication of rinderpest. Vaccine. 7: 484

Waller, P.J. 1993. Towards sustainable nematode parasite control of livestock. Veterinary Parasitology 48: 295. 